\title{
Response of Two Barley Cultivars to Partial Substitution of Mineral Fertilizers by Biofertilizers under New Valley Conditions
}

\author{
Moslim, S.H.A. ${ }^{2}$; R.A. Dawood ${ }^{1}$; F.M.F. Abdel-Motagally ${ }^{1}$ and Kh.A. Amer ${ }^{2}$ \\ ${ }^{1}$ Agronomy Dep., Faculty of Agric., Assiut University, Egypt. \\ ${ }^{2}$ Barley Res. Dep., Field Crops Res. Inst., Agric. Res. Center, Giza, Egypt \\ Received on: $14 / 12 / 2017$ \\ Accepted for publication on: 16/1/2018
}

\section{Abstract}

A field experiments was carried out during of 2014/15 and 2015/16 seasons in the Experimental Farm, Agricultural Research Station of El-Kharga, New Valley Government to study the effects of partially substitution of chemical NPK fertilizers by biofertilizers on two barley cultivars production under New Valley conditions. Seven fertilizers combinations were tested as follows: $\mathrm{F}_{1}: 100 \%$ of recommended NPK fertilizers, $\mathrm{F}_{2}: 75 \%$ of recommended NPK fertilizers + Microbein, $\mathrm{F}_{3}: 50 \%$ of recommended NPK fertilizers + Microbein, $F_{4}: 75 \%$ of recommended NPK fertilizers + Algae extract, $\mathrm{F}_{5}: 50 \%$ of recommended NPK fertilizers + Algae extract, $F_{6}: 75 \%$ of recommended NPK fertilizers + Algae extract + Microbein, and $F_{7}: 50 \%$ of recommended NPK fertilizers + Algae extract + Microbein. Number of spikes $\mathrm{m}^{-}$ ${ }^{2}$, number of grains spike ${ }^{-1}$, weight of 1000-grains, weight of grains spike ${ }^{-1}$, biological yield fed ${ }^{-1}$, grain yield $\mathrm{fed}^{-1}$, straw yield $\mathrm{fed}^{-1}$, and harvest index $(\%)$ were recorded at harvest.

Results indicated that the superiority of Giza 134 cultivar over Giza 132 cultivar was confirmed for most studied traits in both seasons.

Double-inoculation of Algae extract and Microbein plus 75\% of recommended mineral NPK fertilizers represents $10.14,18.50$ and $16.19 \%$ increases in grain, straw and biological yields of barley in the first season; 8.91, 29.42 and $22.15 \%$ in the second season, respectively; compared to the application of $100 \%$ of recommended mineral NPK fertilizers alone.

Giza 134 cultivar fertilized with $75 \%$ chemical NPK + Algae extract + Microbein $\left(\mathrm{F}_{6}\right)$ gave the highest grain yield (2.69 and 2.97 ton $\left.\mathrm{fed}^{-1}\right)$ and biological yield $\left(8.38\right.$ and 9.43 ton fed $\left.^{-1}\right)$ followed by $50 \%$ chemical NPK + Algae extract + Microbein $\left(\mathrm{F}_{7}\right)$ with the same cultivar $\left(2.53\right.$ and 2.88 ton $\left.\mathrm{fed}^{-1}\right)$ and $(8.16$ and 8.95 ton fed $\left.^{-1}\right)$, respectively.

It can be concluded that replacing 25 or $50 \%$ of chemical fertilizers by doubleinoculation of Algae extract + Microbein as biofertilizers to improved yield and its components of Giza 132 and Giza 134 cultivars as well as saving about 25 to $50 \%$ of recommended dose of NPK.

Keyword: NPK fertilization, bio-fertilizers, barley, yield and partial substitution

\section{Introduction}

Barley (Hordeum vulgare L.) is multipurpose winter crop. In Egypt, the major use of barley is for animal feeding, however, there is a recent interest in using the crop in human food. The cultivated area of barley is limited in Nile Valley and Delta due to the competition with other important winter crops. However, it could be cultivated in the Northern Coast of Egypt under rainfed and newly reclaimed soil in the desert area.

Many investigators revealed that yield and its components were 
significantly influenced by various barley cultivars (Ali, 2011 and Mariey et al., 2016). In this regard, Mariey and Khedr (2017) revealed that the maximum values of grain yield were found for the cultivars Giza 2000, Giza 126 and Giza 131 were $\left(14.13,13.16\right.$ and $\left.11.53 \mathrm{t} \mathrm{ha}^{-1}\right)$, respectively.

Recently, there has been an increasing awareness of the undesirable impact of chemical fertilizers on the environment, as well as increasing fertilizers costs led to the strong belief in biological $\mathrm{N}_{2}$ fixation and the use of biofertilizers. Therefore, several works showed that the integrated use of bio and inorganic sources of plant nutrients was enhanced barley productivity. ElSayed et al. (2000) found that Microbein and Azottein caused significant increases in grain yield reached about 24.8 and $27.2 \%$ in the first season and 18.4 and $22.0 \%$ in the second season respectively compared to the un-inoculation. El-Shahat et al. (2014) stated that all the biofertilizers (symbiotic $\mathrm{N}_{2}$ - fixers and Azolla) treatments recorded significant increases for grains and straw yields as compared with uninoculated treatments control.

So, this work was initiated to find out the best NPK fertilization combination with bio-fertilizers and mineral NPK source to reduce the amount of mineral NPK used in fertilization of two barley cultivars.

\section{Materials and Methods}

A field experiment was carried out at the Experimental Farm of El-
Kharga Research, Station, New Valley, Egypt, during 2014/15 and $2015 / 16$, seasons to study the effects of partially substitution of chemical NPK fertilizers by bio-fertilizers on two barley cultivars production under New Valley conditions.

The experimental design was randomizing complete block design (RCBD) using split plot design with four replications. The experimental treatments can be described as follows:

Main plots: Barley cultivars
1. Giza 132
2. Giza 134

Sub plots: Fertilization combinations

$\mathrm{F}_{1}=100 \%$ of recommended NPK fertilizers.

$\mathrm{F}_{2}=75 \%$ of recommended NPK fertilizers + Microbein

$\mathrm{F}_{3}=50 \%$ of recommended NPK fertilizers + Microbein

$\mathrm{F}_{4}=75 \%$ of recommended NPK fertilizers + Algae extract

$\mathrm{F}_{5}=50 \%$ of recommended NPK fertilizers + Algae extract $\mathrm{F}_{6}=75 \%$ of recommended NPK fertilizers + Algae extract + Microbein

$\mathrm{F}_{7}=50 \%$ of recommended NPK fertilizers + Algae extract + Microbein

Some physical and chemical properties of experimental soil is shown in Table 1. Jackson, M.L. (1973). 
Table 1. Some physical and chemical characteristics of the experimental soil.

\begin{tabular}{|c|c|c|}
\hline \multirow{2}{*}{ Soil Characteristics } & \multicolumn{2}{|c|}{ Season } \\
\hline & $2014 / 15$ & $2015 / 16$ \\
\hline Sand \% & 71.00 & 70.25 \\
\hline Silt \% & 9.75 & 9.00 \\
\hline Clay \% & 19.25 & 20.25 \\
\hline Soil texture & Loamy Sand & Loamy Sand \\
\hline $\mathrm{CaCO}_{3} \%$ & 1.93 & 1.95 \\
\hline $\mathrm{pH}$ (1:1 suspension) & 7.5 & 7.5 \\
\hline $\mathrm{EC}(1: 1$ extract $) \mathrm{dS} \mathrm{m}^{-1}$ & 0.56 & 0.57 \\
\hline $\mathrm{OM} \%$ & 0.11 & 0.13 \\
\hline Total N \% & 0.005 & 0.006 \\
\hline $\mathrm{NaHCO}_{3}-\mathrm{P}\left(\mathrm{mg} \mathrm{kg}^{-1}\right)$ & 6.74 & 6.64 \\
\hline Exch-K (mg kg ${ }^{-1}$ soil) & 0.21 & 0.23 \\
\hline
\end{tabular}

Microbin is a commercial multistrains biofertilizer produced by the General Organization for Agricultural Equalization Fund, Ministry of Agriculture and Land Reclamation. It is constituted of a mixture of $\mathrm{P}$ dissolving and $\mathrm{N}_{2}$-fixing bacteria (Azospirillum sp., Bacillus sp. and Pseudomonas sp.). Arabic gum was melted in amount of warm water and was added to the Microbin. Barley grains were added to the mixture of Microbein and the gum and mixed carefully and spread over plastic sheet in shadowed place for a short time before sowing.

Algae extract (Ascophyllum nodosum) is a commercial component. It was applied at rate $2 \mathrm{~L}$ $\mathrm{fed}^{-1}$ with irrigation water at sowing.

Barley grains were hand drilled at the rate of $40 \mathrm{~kg} \mathrm{fed}^{-1}$ on 21 and 15 November in 2014/15 and 2015/16 seasons, respectively. The experimental unit area was $10.5 \mathrm{~m}^{2}$ $(3.0 \mathrm{~m} \mathrm{X} 3.5 \mathrm{~m})$. It included 17 rows, $300 \mathrm{~cm}$ long and $20 \mathrm{~cm}$ apart. The experimental plots were irrigated by underground water using flooding irrigation system.
The recommended dose of NPK was 45,30 and $24 \mathrm{~kg} \mathrm{fed}^{-1}$. $\mathrm{N}$ as ammonium nitrate $(33.5 \% \mathrm{~N}), 30 \mathrm{~kg}$ $\mathrm{P}_{2} \mathrm{O}_{5}$ fed $^{-1}$ as super phosphate $(15 \%$ $\mathrm{P}_{2} \mathrm{O}_{5}$ ) was applied before sowing and $24 \quad \mathrm{~kg} \quad \mathrm{~K}_{2} \mathrm{O} \quad \mathrm{fed}^{-1}$ as potassium sulphate $\left(48 \% \mathrm{~K}_{2} \mathrm{O}\right)$ was applied at 20 days after sowing. Nitrogen fertilizer was added in three doses, $20 \%$ were added at sowing time, $40 \%$ added at 20 days after sowing and the third dose $40 \%$ were applied at 50 days after sowing.

At harvest one square meter was taken randomly from each sub plot to determine yield and its components:

1. Number of spikes $\mathrm{m}^{-2}$.

2. Number of grains spike $^{-1}$ (average of 10 stem).

3. Weight of grains spike ${ }^{-1}$ g (average of 10 stem).

4. Weight of 1000-grains (g).

5. Biological yield (ton fed ${ }^{-1}$ ).

6. Grain yield (ton fed $^{-1}$ ).

7. Straw yield (ton fed ${ }^{-1}$ ).

8. Harvest index (\%) was calculated as follows:

Harvest index $=\frac{\text { Grain yield }\left(\text { ton } \text { fed }^{-1}\right)}{\text { Bio } \log \text { ical yield }\left(\text { ton } \text { fed }^{-1}\right)} \times 100$ 
The obtained data were subjected to standard analysis of variance and the means of treatments were tested for significant differences using the least significant difference method (LSD) at $P=0.05$. The MSTATC (version 2.10) computer program written by Freed et al. (1987) was used to perform all the analysis of variance.

\section{Results and Discussion}

\section{Yield components}

\subsection{Effect of barley cultivars}

The effects of cultivars on number of spikes $\mathrm{m}^{-2}$, number of grains spike ${ }^{-1}$, weight of grains spike ${ }^{-1}$ and weight of 1000-grains of barley are shown in Table 2. The superiority of Giza 134 cultivar over Giza 132 cultivar was confirmed for most studied traits in the both seasons. However, results reveal the superiority of Giza 132 cultivar in weight of 1000-grains in the second season.

The higher mean values of the previous traits indicate the suitable genetic behavior of Giza 134 cultivar with environment factors which may lead to an increasing in number of spikes $\mathrm{m}^{-2}$ and number of grains spike $^{-1}$. Similar trend was obtained by Alam et al. (2007), Zeidan (2007) and Ali (2011) who recoded significant differences between barley genotypes in yield components.

Table. 2. Effect of cultivars on yield components of barley in two growing seasons.

\begin{tabular}{|c|c|c|c|c|c|c|c|c|}
\hline \multirow{2}{*}{ cultivars } & \multicolumn{2}{|c|}{$\begin{array}{c}\text { Number of } \\
\text { spikes m }^{-2}\end{array}$} & \multicolumn{2}{c|}{$\begin{array}{c}\text { Number of } \\
\text { grains spike }^{-1}\end{array}$} & \multicolumn{2}{c|}{$\begin{array}{c}\text { Weight of grains } \\
\text { spike-1 }^{-1}\end{array}$} & $\begin{array}{c}\text { Weight of 1000- } \\
\text { (grains (g) }\end{array}$ \\
\cline { 2 - 9 } & $2014 / 15$ & $2015 / 16$ & $2014 / 15$ & $2015 / 16$ & $2014 / 15$ & $2015 / 16$ & $2014 / 15$ & $2015 / 16$ \\
\hline Giza 132 & 333.09 & 329.01 & 35.25 & 40.35 & 1.21 & 1.47 & 34.46 & 36.26 \\
\hline Giza 134 & 371.09 & 375.61 & 41.18 & 48.33 & 1.57 & 1.69 & 38.4 & 34.91 \\
\hline F Test & $* *$ & $*$ & $*$ & $*$ & $* *$ & $*$ & $*$ & $\mathrm{~ns}$ \\
\hline
\end{tabular}

$*$ and $* *$ indicated significant at $5 \%$ and $1 \%$ levels of probability, respectively.

ns $=$ non- significant

\subsection{Effect of fertilization combinations}

Data in Table 3 indicate that number of spikes $\mathrm{m}^{-2}$, number of grains spike ${ }^{-1}$ and weight of grains spike $^{-1}$ as well as weight of 1000grains of barley were highly significantly affected by partial replacement of chemical NPK by biofertilizers (Microbin and Algae extract). Application of the $75 \%$ mineral NPK + Algae extract + Microbein combination $\left(\mathrm{F}_{6}\right)$ records the highest mean values of number of spikes $\mathrm{m}^{-2}$, weight of grains spike ${ }^{-1}$ of barley followed by the $50 \%$ chemical $\mathrm{NPK}+$ Algae extract + Microbein combination $\left(\mathrm{F}_{7}\right)$ without significant differences. $\mathrm{F}_{6}$ treatment increased number of spikes $\mathrm{m}^{-2}$ by $15.97,21.97$, $29.80, \quad 18.71$ and $24.08 \%$ as compared to $\mathrm{F}_{1}, \mathrm{~F}_{2}, \mathrm{~F}_{3}, \mathrm{~F}_{4}$ and $\mathrm{F}_{5}$, respectively in the first season, being $16.31,25.40,27.12, \quad 22.20$ and $25.78 \%$ in the second season in the same order.

Fertilized barley plants with $\mathrm{F}_{6}$ and $F_{7}$ gave the highest mean values of number of grains spike ${ }^{-1}$ without significant variations in the first season only. The increment percentages of number of grains spike ${ }^{-1}$ due to $F_{6}$ and $F_{7}$ fertilizing compared with $\mathrm{F}_{1}$ recommended 
NPK fertilization $\left(\mathrm{F}_{1}\right)$ were 14.13 and $14.48 \%$, respectively in the first season. Meanwhile, applied $\mathrm{F}_{6}$ combination recoded significant differences compared with the rest fertilization combinations. $\mathrm{F}_{6}$ treatment increased number of grains spike $^{-1}$ by $29.89 \%$ compared with recommended chemical fertilization $F_{1}$ in the second season.

Table 3. Effect of fertilization combinations on yield components of barley in the two growing seasons.

\begin{tabular}{|c|c|c|c|c|c|c|c|c|}
\hline \multirow{2}{*}{ Treat. } & \multicolumn{2}{|c|}{$\begin{array}{c}\text { Number of spikes } \\
\mathbf{m}^{-2}\end{array}$} & \multicolumn{2}{c|}{$\begin{array}{c}\text { Number of } \\
\text { grains spike }^{-1}\end{array}$} & \multicolumn{2}{c|}{$\begin{array}{c}\text { Weight of 1000- } \\
\text { grains (g) }\end{array}$} & \multicolumn{2}{c|}{$\begin{array}{c}\text { Weight of grains } \\
\text { spike }\end{array}$} \\
\cline { 2 - 9 } & $2014 / 15$ & $2015 / 16$ & $2014 / 15$ & $2015 / 16$ & $2014 / 15$ & $2015 / 16$ & $2014 / 15$ & $2015 / 16$ \\
\hline $\mathrm{F}_{1}$ & 349.06 & 351.50 & 35.38 & 40.85 & 1.40 & 1.49 & 39.27 & 36.65 \\
\hline $\mathrm{F}_{2}$ & 332.38 & 326.03 & 40.00 & 38.47 & 1.32 & 1.35 & 33.14 & 35.36 \\
\hline $\mathrm{F}_{3}$ & 311.88 & 321.60 & 34.50 & 39.67 & 1.19 & 1.24 & 34.32 & 31.63 \\
\hline $\mathrm{F}_{4}$ & 341.00 & 334.55 & 38.88 & 46.29 & 1.36 & 1.63 & 35.03 & 35.21 \\
\hline $\mathrm{F}_{5}$ & 326.25 & 325.03 & 37.75 & 44.17 & 1.38 & 1.44 & 36.56 & 32.75 \\
\hline $\mathrm{F}_{6}$ & 404.81 & 408.83 & 40.38 & 53.06 & 1.68 & 2.10 & 41.65 & 39.61 \\
\hline $\mathrm{F}_{7}$ & 399.25 & 398.65 & 40.63 & 47.88 & 1.43 & 1.81 & 35.04 & 37.90 \\
\hline $\mathrm{F}-$ Test & $* *$ & $* *$ & $* *$ & $* *$ & $* *$ & $* *$ & $* *$ & $* *$ \\
\hline LSD 0.05 & 25.84 & 28.67 & 3.16 & 4.82 & 3.98 & 2.77 & 0.14 & 0.17 \\
\hline
\end{tabular}

$*$ and $* *$ indicated significant at $5 \%$ and $1 \%$ levels of probability, respectively.

Also, $\mathrm{F}_{6}$ combination gave the maximum mean values of 1000 grains weight followed by $F_{7}$ and $F_{1}$ in the second seasons.

The present results cleared that the positive effect of application of Microbin and Algae extract with 75 or $50 \%$ chemical NPK fertilization may be due to the enhancing plant growth which increased plant metabolites which encouraged the growth of microorganisms through the save of chemical NPK fertilizers. These results are confirmed with those reported by Abd El-Lattief (2012) and Zaki et al. (2012).

\subsection{Effect of interaction}

The effect of interaction on number of spikes $\mathrm{m}^{-2}$, number of grains spike ${ }^{-1}$ and weight of grains spike $^{-1}$ as well as weight of 1000grains are shown in Table, 4. Data reveal that there no significant differences were observed between treatments on the studied traits. Fertilized Giza 134 cultivar fertilized with the $75 \%$ of recommended mineral NPK + Algae extract + Microbein combination $\left(\mathrm{F}_{6}\right)$ gave the highest mean values of the most studied traits. Meanwhile, Giza 132 cultivar supplied with $75 \%$ of recommended mineral NPK + Microbein combination recoded the lowest mean values of the most studied traits. 
Table 4. Effect of fertilization combinations on yield components of barley in two growing seasons.

\begin{tabular}{|c|c|c|c|c|c|c|c|c|c|}
\hline \multirow[t]{2}{*}{ Cultivar } & \multirow{2}{*}{$\begin{array}{l}\text { Fert. } \\
\text { comb. }\end{array}$} & \multicolumn{2}{|c|}{ Number of spikes $\mathrm{m}^{-2}$} & \multicolumn{2}{|c|}{$\begin{array}{c}\text { Number of grains } \\
\text { spike }^{-1}\end{array}$} & \multicolumn{2}{|c|}{$\begin{array}{c}\text { Weight of 1000-grains } \\
\text { (g) }\end{array}$} & \multicolumn{2}{|c|}{$\begin{array}{c}\text { Weight of grains } \\
\text { spike }^{-1} \text { (g) }\end{array}$} \\
\hline & & $2014 / 15$ & $2015 / 16$ & $2014 / 15$ & $2015 / 16$ & $2014 / 15$ & $2015 / 16$ & $2014 / 15$ & $2015 / 16$ \\
\hline \multirow{7}{*}{ Giza 132} & $\mathrm{~F} 1$ & 329.88 & 324.00 & 33.75 & 35.65 & 34.60 & 37.10 & 1.17 & 1.31 \\
\hline & $\mathrm{F} 2$ & 307.38 & 305.55 & 35.25 & 33.20 & 33.21 & 36.18 & 1.17 & 1.20 \\
\hline & F3 & 278.50 & 304.20 & 33.00 & 36.60 & 31.73 & 31.83 & 1.05 & 1.15 \\
\hline & F4 & 322.50 & 318.60 & 34.75 & 42.80 & 35.16 & 36.68 & 1.22 & 1.58 \\
\hline & F5 & 302.50 & 305.55 & 35.00 & 38.05 & 35.48 & 33.68 & 1.24 & 1.28 \\
\hline & F6 & 400.13 & 378.90 & 37.25 & 49.95 & 38.94 & 40.00 & 1.45 & 2.00 \\
\hline & F7 & 390.75 & 366.30 & 37.75 & 46.20 & 32.08 & 38.40 & 1.21 & 1.78 \\
\hline \multirow{7}{*}{ Giza 134} & $\mathrm{~F} 1$ & 368.25 & 379.00 & 37.00 & 46.04 & 43.94 & 36.20 & 1.63 & 1.68 \\
\hline & $\mathrm{F} 2$ & 357.38 & 346.50 & 44.75 & 43.73 & 33.07 & 34.55 & 1.48 & 1.50 \\
\hline & F3 & 345.25 & 339.00 & 36.00 & 42.74 & 36.90 & 31.43 & 1.33 & 1.33 \\
\hline & F4 & 359.50 & 350.50 & 43.00 & 49.77 & 34.91 & 33.75 & 1.50 & 1.68 \\
\hline & F5 & 350.00 & 344.50 & 40.50 & 50.30 & 37.65 & 31.83 & 1.53 & 1.60 \\
\hline & F6 & 409.50 & 438.75 & 43.50 & 56.18 & 44.35 & 39.23 & 1.92 & 2.20 \\
\hline & F7 & 407.75 & 431.00 & 43.50 & 49.56 & 38.01 & 37.40 & 1.66 & 1.85 \\
\hline \multicolumn{2}{|c|}{ F Test } & ns & ns & $\mathrm{ns}$ & $\mathrm{ns}$ & $\mathrm{ns}$ & $\mathrm{ns}$ & $\mathrm{ns}$ & ns \\
\hline \multicolumn{2}{|c|}{ LSD 0.05} & - & - & - & - & - & - & - & - \\
\hline
\end{tabular}

ns = non- significant.

\section{Yield}

\subsection{Effect of barley cultivars}

Presented data in Table 5 show the effect of cultivars on biological, grain, straw and yields as well as harvest index of barley.

Data illustrate significant differences between the two cultivars in all the abovementioned traits, except straw yield in the second season and biological yield in the first season. Giza 134 cultivar gave the highest mean values for all studied traits in both growing seasons.

The superiority of Giza 134 cultivar than Giza 132 cultivar because it is giving the highest average of weight of grain spike ${ }^{-1}$, number of spikes $\mathrm{m}^{-2}$ (Table, 2) in both seasons. These results are in agreement with those reported by ElBanna et al. (2011) and Mariey and Khedr (2017).

Table. 5. Effect of cultivars on yield of barley in two growing seasons.

\begin{tabular}{|c|c|c|c|c|c|c|c|c|}
\hline \multirow{2}{*}{ cultivars } & \multicolumn{2}{|c|}{$\begin{array}{c}\text { Biological yield } \\
\text { (ton fed }^{-1} \text { ) }\end{array}$} & \multicolumn{2}{c|}{$\begin{array}{c}\text { Straw yield } \\
\text { (ton fed }^{-1} \text { ) }\end{array}$} & \multicolumn{2}{c|}{$\begin{array}{c}\text { Grain yield } \\
\text { (ton fed }^{-1} \text { ) }\end{array}$} & \multicolumn{2}{c|}{$\begin{array}{c}\text { Harvest index } \\
\text { (\%) }\end{array}$} \\
\cline { 2 - 9 } & $2014 / 15$ & $2015 / 16$ & $2014 / 15$ & $2015 / 16$ & $2014 / 15$ & $2015 / 16$ & $2014 / 15$ & $2015 / 16$ \\
\hline Giza 132 & 6.54 & 6.96 & 4.87 & 4.75 & 1.67 & 2.21 & 26.2 & 31.65 \\
\hline Giza 134 & 7.41 & 7.71 & 5.00 & 5.07 & 2.41 & 2.64 & 33.23 & 34.67 \\
\hline F Test & ns & $*$ & $*$ & ns & $*$ & $* *$ & $*$ & $*$ \\
\hline
\end{tabular}

$*$ and $* *$ indicated significant at 5\% 1\% levels of probability, respectively.

ns $=$ non- significant.

\subsection{Effect of fertilization combinations}

It is clear from data in Table 6 that the effects of partial replacement of chemical fertilizers by bio fertilizers on the biological, grain and straw yields were highly significant, while, fertilization combinations have insignificant effect on harvest index.

Application of doubleinoculation of Algae extract and Microbein $+75 \%$ chemical NPK (F6) surpassed other fertilization combinations on grain, straw and 
biological yields. This combination represents $10.14,18.50$ and $16.19 \%$ increases in grain, straw and biological yields of barley in the first season being $8.91,29.42$ and $22.15 \%$ in the second season, respectively; compared to the application of $100 \%$ chemical NPK $\left(\mathrm{F}_{1}\right)$.

Partial substitution of $50 \%$ of chemical NPK by Algae extract and Microbein $\left(\mathrm{F}_{7}\right)$ came in the second rank without significant differences compared to $\mathrm{F} 6$ combination. The $\mathrm{F}_{7}$ combination increased abovementioned traits by $3.38,15.04$ and $11.75 \%$ in the first season; 5.04, 20.90 and $15.27 \%$ in the second season, respectively; compared to the application of $100 \%$ chemical NPK $\left(\mathrm{F}_{1}\right)$.

This is logic since the same fertilizer combination gave the highest mean values with resend to yield component studied traits as mention before.

A similar conclusion had been achieved by Salantur et al. (2006) and Mohammed et al. (2012).

Table 6. Effect of fertilization combinations on yield of barley in two growing seasons.

\begin{tabular}{|c|c|c|c|c|c|c|c|c|}
\hline \multirow[t]{2}{*}{ Treat. } & \multicolumn{2}{|c|}{$\begin{array}{l}\text { Grain yield } \\
\left.\text { (ton fed }^{-1}\right)\end{array}$} & \multicolumn{2}{|c|}{$\begin{array}{l}\text { Straw yield } \\
\left.\text { (ton fed }^{-1}\right)\end{array}$} & \multicolumn{2}{|c|}{$\begin{array}{l}\text { Biological yield } \\
\left.\quad \text { ton fed }^{-1}\right)\end{array}$} & \multicolumn{2}{|c|}{$\begin{array}{c}\text { Harvest index } \\
(\%)\end{array}$} \\
\hline & $2014 / 15$ & $2015 / 16$ & $2014 / 15$ & $2015 / 16$ & $2014 / 15$ & $2015 / 16$ & $2014 / 15$ & $2015 / 16$ \\
\hline $\mathrm{F}_{1}$ & 2.07 & 2.58 & 4.92 & 4.69 & 6.98 & 7.27 & 29.73 & 35.72 \\
\hline $\mathrm{F}_{2}$ & 2.04 & 2.22 & 4.54 & 4.58 & 6.58 & 6.80 & 31.12 & 32.41 \\
\hline $\mathrm{F}_{3}$ & 1.84 & 2.01 & 3.80 & 4.09 & 5.64 & 6.11 & 32.63 & 33.13 \\
\hline $\mathrm{F}_{4}$ & 2.08 & 2.60 & 5.48 & 4.79 & 7.56 & 7.39 & 28.28 & 35.11 \\
\hline $\mathrm{F}_{5}$ & 1.84 & 2.05 & 4.33 & 4.46 & 6.17 & 6.52 & 30.21 & 31.69 \\
\hline $\mathrm{F}_{6}$ & 2.28 & 2.81 & 5.83 & 6.07 & 8.11 & 8.88 & 28.25 & 31.74 \\
\hline $\mathrm{F}_{7}$ & 2.14 & 2.71 & 5.66 & 5.67 & 7.80 & 8.38 & 27.79 & 32.29 \\
\hline F-Test & $* *$ & $* *$ & $*$ & $* *$ & $*$ & $* *$ & ns & ns \\
\hline LSD 0.05 & 0.23 & 0.32 & 1.30 & 0.53 & 1.48 & 0.58 & - & - \\
\hline
\end{tabular}

Data in Table 6 show that harvest index was insignificant influenced by various studied fertilization combinations. Fertilized barley plants with $\mathrm{F}_{3}$ combination gave the highest mean value of harvest index $(32.63 \%)$ followed by $\mathrm{F}_{2}(31.12 \%)$ and $\mathrm{F}_{5}(30.21 \%)$ in the first season. Meanwhile, the highest mean value of harvest index $(35.72 \%)$ was obtained by $F_{1}$ in the second season. Thus, it is indicated that using bio-fertilizers caused an increase in harvest index due to effect on dry weight and allocating more photosynthetic matters to grain. These results are in harmony with those reported by Zaki et al. (2012) and Abd El-Razek and El-Sheshtawy (2013).

\subsection{Effect of interaction}

The effects of interactions on biological, grain and straw yields as well as harvest index in both seasons are shown in Table 7. The interactions between barley cultivars and fertilization combinations have insignificant effects on the studied traits, except straw yield in the first season and biological yield in the second season.

Giza 134 fertilized with $75 \%$ of recommended NPK + Algae extract + Microbein $\left(\mathrm{F}_{6}\right)$ gave the highest grain 
yield $\left(2.69\right.$ and 2.97 ton $\left.\mathrm{fed}^{-1}\right)$ and biological yield ( 8.38 and 9.43 ton fed $^{-1}$ ) followed by $50 \%$ chemical NPK + Algae extract + Microbein
$\left(\mathrm{F}_{7}\right)$ with the same cultivar $(2.53$ and 2.88 ton $\left.\mathrm{fed}^{-1}\right)$ and $(8.16$ and 8.95 ton $\left.\mathrm{fed}^{-1}\right)$, respectively.

Table 7. Effect of cultivars and NPK fertilization combinations on yield components of barley in two growing seasons.

\begin{tabular}{|c|c|c|c|c|c|c|c|c|c|}
\hline \multirow[t]{2}{*}{ Cultivar } & \multirow[t]{2}{*}{ NPK fert. } & \multicolumn{2}{|c|}{$\begin{array}{l}\text { Grain yield } \\
\left.\text { (ton fed }^{-1}\right)\end{array}$} & \multicolumn{2}{|c|}{ 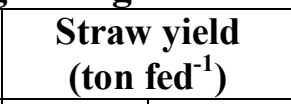 } & \multicolumn{2}{|c|}{$\begin{array}{l}\text { Biological yield } \\
\quad\left(\text { ton } \text { fed }^{-1}\right)\end{array}$} & \multicolumn{2}{|c|}{$\begin{array}{c}\text { Harvest index } \\
(\%)\end{array}$} \\
\hline & & 2014/15 & 2015/16 & 2014/15 & 2015/16 & 2014/15 & 2015/16 & $2014 / 15$ & $2015 / 16$ \\
\hline \multirow{7}{*}{ Giza 132} & $\overline{F_{1}}$ & 1.70 & 2.46 & 4.83 & 4.58 & 6.52 & 7.03 & 26.22 & 34.89 \\
\hline & $\mathrm{F}_{2}$ & 1.68 & 1.87 & 4.41 & 4.44 & 6.09 & 6.31 & 27.72 & 29.65 \\
\hline & $\mathrm{F}_{3}$ & 1.51 & 1.80 & 3.73 & 4.50 & 5.24 & 6.30 & 28.97 & 28.70 \\
\hline & $\mathrm{F}_{4}$ & 1.71 & 2.35 & 5.40 & 4.88 & 7.10 & 7.23 & 24.76 & 32.28 \\
\hline & $\mathrm{F}_{5}$ & 1.51 & 1.83 & 4.07 & 3.88 & 5.58 & 5.72 & 27.55 & 31.71 \\
\hline & $\mathrm{F}_{6}$ & 1.86 & 2.66 & 5.98 & 5.69 & 7.84 & 8.34 & 24.01 & 31.92 \\
\hline & $\mathrm{F}_{7}$ & 1.76 & 2.53 & 5.68 & 5.27 & 7.44 & 7.81 & 24.16 & 32.38 \\
\hline \multirow{7}{*}{ Giza 134} & $\mathrm{~F}_{1}$ & 2.45 & 2.70 & 5.00 & 4.80 & 7.45 & 7.51 & 33.24 & 36.55 \\
\hline & $\mathrm{F}_{2}$ & 2.41 & 2.57 & 4.66 & 4.73 & 7.07 & 7.30 & 34.52 & 35.18 \\
\hline & $\mathrm{F}_{3}$ & 2.17 & 2.23 & 3.87 & 3.69 & 6.04 & 5.93 & 36.29 & 37.55 \\
\hline & $\mathrm{F}_{4}$ & 2.46 & 2.86 & 5.56 & 4.70 & 8.01 & 7.55 & 31.79 & 37.94 \\
\hline & $\mathrm{F}_{5}$ & 2.18 & 2.27 & 4.59 & 5.05 & 6.76 & 7.32 & 32.87 & 31.68 \\
\hline & $\mathrm{F}_{6}$ & 2.69 & 2.97 & 5.69 & 6.46 & 8.38 & 9.43 & 32.48 & 31.56 \\
\hline & F7 & 2.53 & 2.88 & 5.63 & 6.07 & 8.16 & 8.95 & 31.42 & 32.20 \\
\hline \multicolumn{2}{|c|}{ F Test } & ns & ns & ns & $*$ & ns & $*$ & ns & ns \\
\hline \multicolumn{2}{|c|}{ LSD 0.05} & - & - & - & 0.75 & - & 0.82 & - & - \\
\hline
\end{tabular}

$*$ and $* *$ indicated significant at $5 \%$ and $1 \%$ levels of probability, respectively. $\mathrm{ns}=$ non- significant.

Straw yield of barley hadn't clear response trend to the interaction effects between barley cultivars and fertilization combinations. Giza 132 cultivar was surpassed Giza 134 cultivar with $75 \%$ of recommended $\mathrm{NPK}+$ Algae extract + Microbein $\left(\mathrm{F}_{6}\right)$ in the first season meanwhile, Giza 134 cultivar was the best in the second season with the same fertilization combination.

The interaction effect between barley cultivars and fertilization combinations was insignificant with regard to harvest index in the both studied seasons (Table, 7). Generally, Giza 134 cultivar was superior to Giza 132 cultivar under most fertilization combinations. In this regard, fertilized Giza 134 cultivar plants with $\mathrm{F}_{3}$ and $\mathrm{F}_{4}$ gave the highest mean values of harvest index in the first season and second season, respectively.

\section{Conclusion}

Using bio-fertilizers is necessary to rationalize the consumption of the chemical fertilizers minimize the environmental pollution and improve soil quality. So, it can be replaced 25 or $50 \%$ of chemical fertilizers by double-inoculation of Algae extract + Microbein as bio-fertilizers to improved barley yield and its components as well as saving about 25 to $50 \%$ of recommended dose of NPK.

\section{References}

Abd El-Lattief, E.A. (2012). Improving bread wheat productivity and 
reduce use of mineral nitrogen by inoculation with Azotobacter and Azospirillum under Arid Environment in Upper Egypt. International Conference on Applied Life Sciences (ICALS2012) Turkey, September 1012.

Abd El-Razek, U.A. and A.A. El-Sheshtawy (2013). Response of some wheat varieties to bio and mineral nitrogen fertilizers. Asian J. Crop Sci.: 1-9.

Alam M.Z., S.A. Haider and N.K. Paul (2007). Yield and Yield Components of Barley (Hordeum vulgare L.) cultivars in Relation to Nitrogen Fertilizer. J. Appl. Sci. Res., 3 (10): 1022-1026.

Ali, E.A. (2011). Impact of nitrogen application time on grain and protein yields as well as nitrogen use efficiency of some two-row barley cultivars in sandy soil. AmericanEurasian J. Agric. \& Environ. Sci., 10 (3): 425-433.

El-Banna, M.N., M.A.A. Nassar, M.N. Mohamed and M.A. Boseely (2011). Evaluation of 16 barley genotypes under calcareous soil conditions in Egypt. J. Agric. Sci., 3 (1): 105-121.

El-Sayed, A.A., R.A. Abo Elenein, E.E. Shalaby, M.A. Shalan and M.A. Said (2000). Response of barley to biofertilizer with $\mathrm{N}$ and $\mathrm{P}$ application under newly reclaimed areas in Egypt. $3^{\text {rd }}$ International Crop Science Congress (ICSC), Hamburg-Germany, August 17-22.

El-Shahat, R.M., A.E.A. Sherif and F.M. Mohamed (2014). Response of barley grown in saline soil to bio-fertilizer as a partial substitutive of mineral fertilizer. Glob. J. Sci. Res., 2 (5): 144-153.

Freed, R.P., S.P. Eisensmith, S. Goelz, D. Reicozky, W.W. Smail and P. Woberg (1987). MSTAT. A Softwar
Program for Design, Management and Analysis of Agronomic Research Experiments. Dep. Crop and Soil Sci; Michigan Stat University, USA.

Jackson, M.L. (1973). Soil chemical analysis. Prentice-Hall, Inc. Englewood Cliffs, N.J. New Delhi.

Mariey, S., M.A. Farid and I.A. Khatab (2016). Physiological and molecular characterization of some Egyptian barley (Hordeum vulgare L.) cultivars for salt tolerance. Egypt. J. Genet. Cytol., 45: 367-382.

Mariey, S.A. and R.A. Khedr (2017). Evaluation of some Egyptian barley cultivars under water stress conditions using drought tolerance indices and multivariate analysis. J. Sus. Agric. Sci., 43 (2): 105- 114.

Mohammed, S.S., A.G. Osman, A.M. Mohammed A.S. Abdalla, A.M. Sherif and A.M.E. Rugheim (2012). Effects of organic and microbial fertilization on wheat growth and yield. Int. Res. J. Agric. Sci. Soil Sci., 2 (4): 149-154.

Salantur, A., A. Ozturk and S. Akten (2006). Growth and yield response of spring wheat (Triticum aestivum L.) to inoculation with rhizobacteria. Plant Soil Eviron., 52 (3): 111-118.

Zaki, N.M., M.A. Gomaa, F.I. Radwan, M.S. Hassanein and A.M.Wali (2012). Effect of mineral, organic and bio-fertilizers on yield, yield components and chemical composition of some wheat cultivars. Journal of Applied Sciences Research, 8 (1): 174-191.

Zeidan, M.S. (2007). Response of Some Barley Cultivars to Nitrogen Sources and Rates Grown in Alkaline Sandy Soil. Research J. Agric. and Biological Sci., 3 (6): 934-938. 
استجابة صنفين من الثعير للإحلا الجزئي للأسمدة المعدنية بالأسمدة الحيوية تحت ظروف

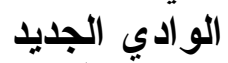

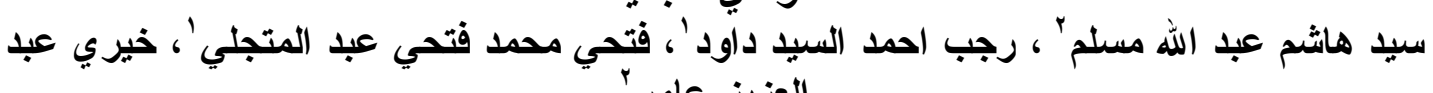

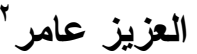

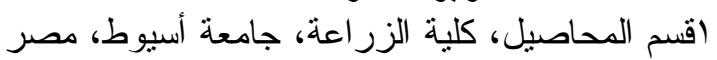

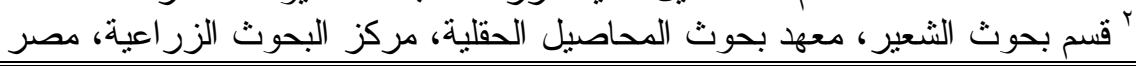

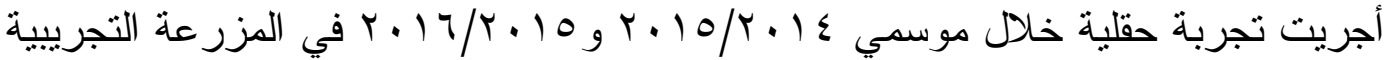

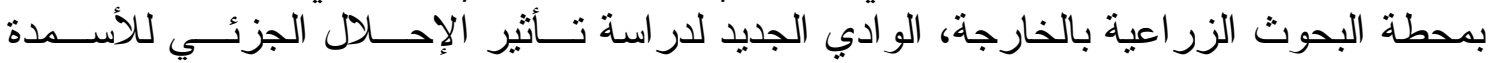

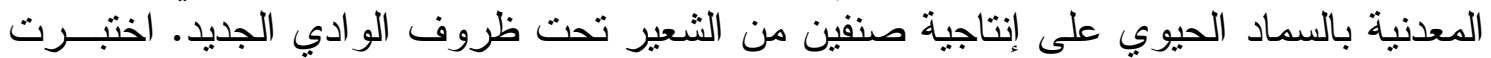

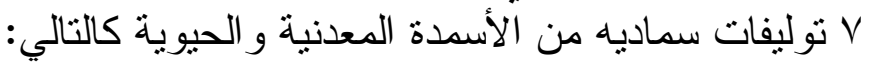

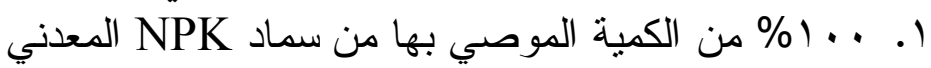

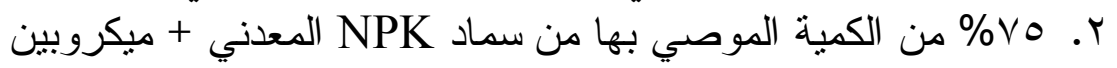

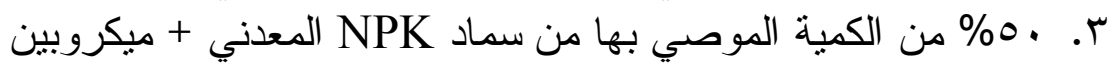

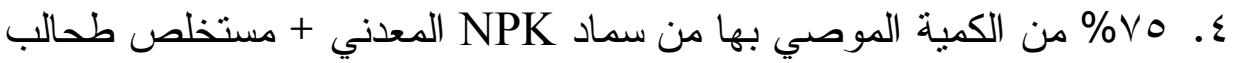

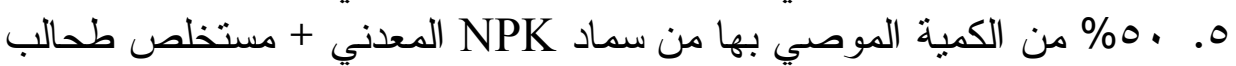
7. طحالب V. . • \% من الكمية الموصي بها من سماد NPK المعـدني + ميكـروبين + مـستخلص طحالب

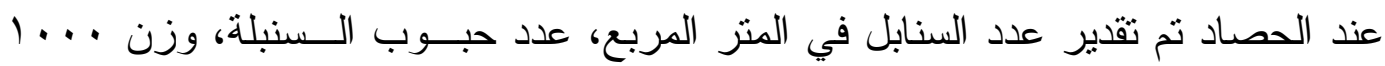

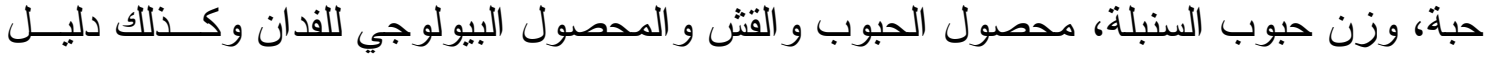

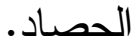

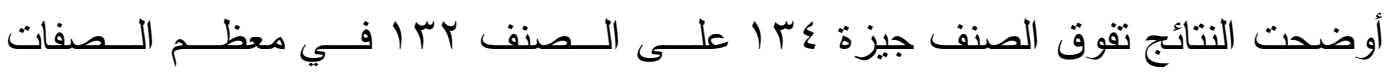

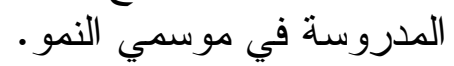

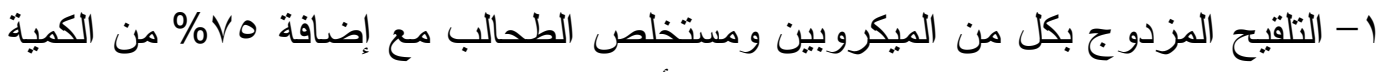

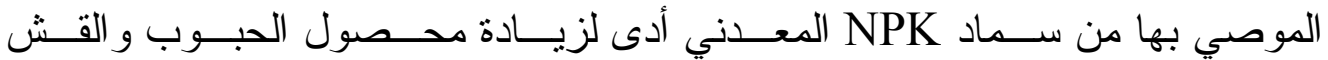

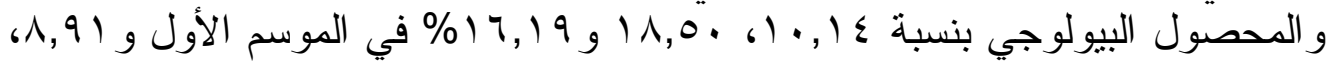

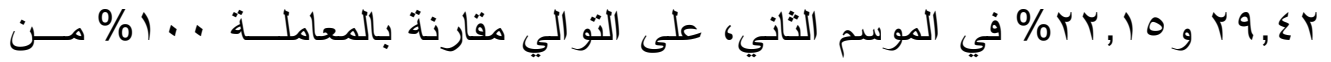

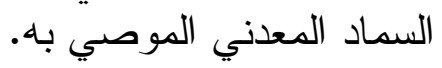

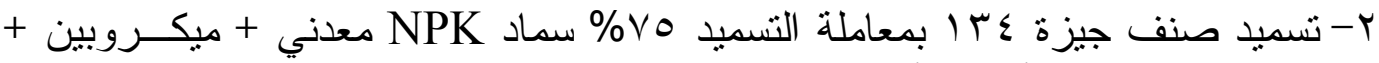

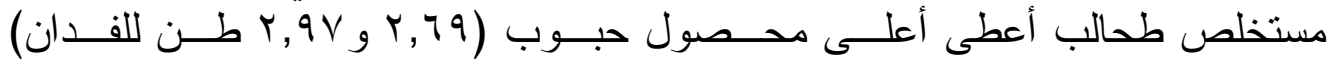

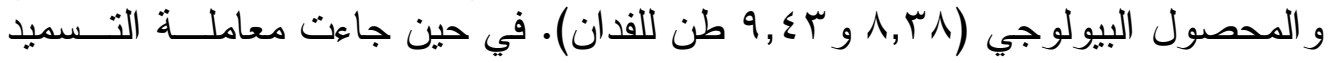

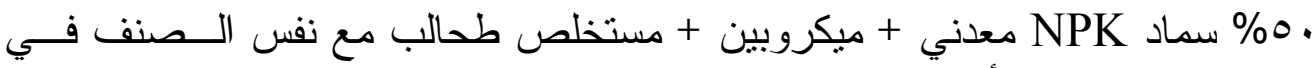

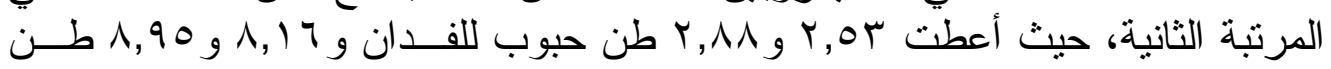

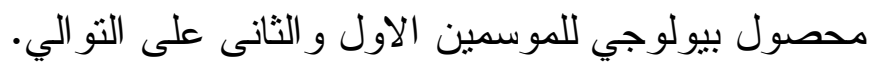

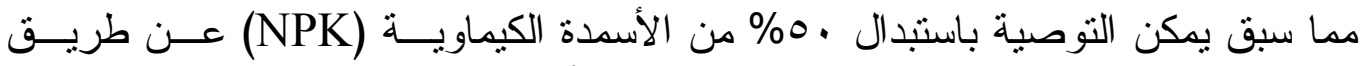

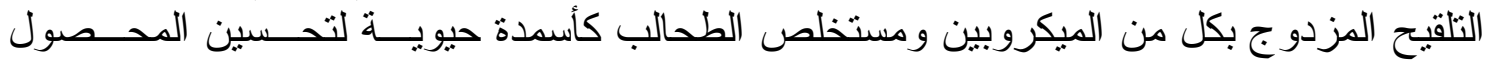

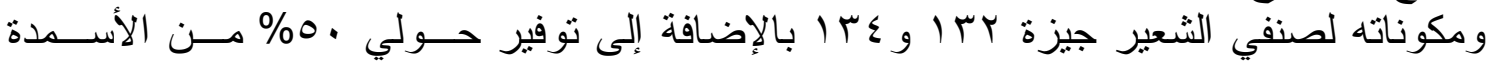

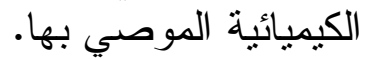

